\title{
Sympathetic vasoconstriction in skeletal muscle: modulatory effects of aging, exercise training, and $\operatorname{sex}^{1}$
}

Darren S. DeLorey

\begin{abstract}
The sympathetic nervous system (SNS) is a critically important regulator of the cardiovascular system. The SNS controls cardiac output and its distribution, as well as peripheral vascular resistance and blood pressure at rest and during exercise. Aging is associated with increased blood pressure and decreased skeletal muscle blood flow at rest and in response to exercise. The mechanisms responsible for the blunted skeletal muscle blood flow response to dynamic exercise with aging have not been fully elucidated; however, increased muscle sympathetic nerve activity (MSNA), elevated vascular resistance, and a decline in endothelium-dependent vasodilation are commonly reported in older adults. In contrast to aging, exercise training has been shown to reduce blood pressure and enhance skeletal muscle vascular function. Exercise training has been shown to enhance nitric oxide-dependent vascular function and may improve the vasodilatory capacity of the skeletal muscle vasculature; however, surprisingly little is known about the effect of exercise training on the neural control of circulation. The control of blood pressure and skeletal muscle blood flow also differs between men and women. Blood pressure and MSNA appear to be lower in young women than in men. However, females experience a larger increase in MSNA with aging compared with males. The mechanism(s) underlying the altered SNS control of vascular function in females remains to be determined.
\end{abstract}

Novelty:

- This review summarizes our current understanding of the effects of aging, exercise training, and sex on sympathetic vasoconstriction at rest and during exercise.

- Areas where additional research is needed are also identified.

Key words: sympatholysis, vascular conductance, blood flow.

Résumé : Le système nerveux sympathique ("SNS ») est un régulateur extrêmement important du système cardiovasculaire. Le SNS contrôle le débit cardiaque et sa distribution ainsi que la résistance vasculaire périphérique et la pression artérielle au repos et pendant l'exercice. Le vieillissement est associé à une augmentation de la pression artérielle et à une diminution du débit sanguin dans les muscles squelettiques au repos et en réponse à l'exercice. Les mécanismes responsables de la réponse émoussée du débit sanguin dans les muscles squelettiques à l'exercice dynamique avec le vieillissement ne sont pas entièrement élucidés; cependant, une augmentation de l'activité des nerfs sympathiques musculaires (" MSNA »), une résistance vasculaire élevée et une diminution de la vasodilatation dépendante de l'endothélium sont fréquemment rapportées chez les personnes âgées. Contrairement au vieillissement, l'entraînement physique réduit, selon des études, la pression artérielle et améliore la fonction vasculaire des muscles squelettiques. Études à l'appui, l'entraînement physique améliore la fonction vasculaire dépendante de l'oxyde nitrique et peut améliorer la capacité vasodilatatrice du système vasculaire des muscles squelettiques; néanmoins, étonnamment, on sait peu de choses sur l'effet de l'entraînement physique sur le contrôle neural de la circulation. Le contrôle de la pression artérielle et du débit sanguin des muscles squelettiques diffère aussi entre les hommes et les femmes. La pression artérielle et la MSNA semblent être plus faibles chez les jeunes femmes que chez les hommes. Toutefois, les femmes présentent par rapport aux hommes une augmentation plus importante de la MSNA avec le vieillissement. Le(s) mécanisme(s) du contrôle altéré du SNS de la fonction vasculaire chez les femmes restent à déterminer. [Traduit par la Rédaction]

Les nouveautés :

- Cette analyse documentaire présente en bref notre compréhension actuelle des effets du vieillissement, de l'entraînement physique et du sexe sur la vasoconstriction sympathique au repos et pendant l'exercice.

- Les domaines où des recherches supplémentaires sont essentielles sont également identifiés.

Mots-clés : sympatholyse, conductance vasculaire, flux sanguin.

\section{Introduction}

The sympathetic branch of the autonomic nervous system is a critically important regulator of the cardiovascular (CV) system.
Efferent sympathetic nerve activity, arising from cardiovascular nuclei in the brainstem, contributes to the control of cardiac contractile and pacemaker cell activity and vascular smooth muscle contractile state, thereby regulating cardiac output and

Received 26 May 2021. Accepted 26 July 2021.

D.S. DeLorey. Faculty of Kinesiology, Sport, and Recreation, University of Alberta, Edmonton, AB T6G 2H9, Canada.

Email for correspondence: ddelorey@ualberta.ca.

${ }^{1} 2019$ APNM Presidents' Lecture Award (Canadian Society for Exercise Physiology (CSEP)).

(c) 2021 The Author(s). Permission for reuse (free in most cases) can be obtained from copyright.com. 
its distribution, as well as peripheral vascular resistance and blood pressure (Dampney 1994).

The skeletal muscle is a large vascular bed that receives a substantial portion of cardiac output. At rest, approximately $20 \%$ of cardiac output is delivered to skeletal muscle (Rowell 1993). During dynamic whole-body exercise, skeletal muscle blood flow increases in concert with metabolic demand, and as much as $>\mathbf{9 0 \%}$ of cardiac output may be directed to skeletal muscle during maximal intensity exercise (Rowell 1993). Thus, the dynamic regulation of vascular resistance in the skeletal muscle vasculature is of paramount importance for the control of tissue blood flow and the maintenance of blood pressure at rest and during exercise.

Aging is associated with increased blood pressure and decreased skeletal muscle blood flow at rest and in response to exercise (Dinenno et al. 1999, 2001a; 2001b; Moreau et al. 2003, 2007). The ageassociated decline in skeletal muscle blood flow has been linked to a reduction in exercise capacity, decreased physical activity, and the pathogenesis of metabolic and CV disease (Lind and Lithell 1993). The mechanisms responsible for the blunted skeletal muscle blood flow response to dynamic exercise in older humans and animals have not been fully elucidated; however, increased muscle sympathetic nerve activity (MSNA), elevated vascular resistance, and a decline in endothelium-dependent vasodilation are commonly reported in older adults (Beere et al. 1999; Hammer and Boegehold 2005; Lawrenson et al. 2003; Poole et al. 2003; Proctor et al.1998, 2003a).

In contrast to aging, exercise training has been shown to reduce blood pressure and enhance skeletal muscle vascular function at rest and during exercise (Thijssen et al. 2010). Exercise training has been shown to enhance nitric oxide (NO)-dependent vascular function (Jendzjowsky et al. 2014a; Just et al. 2016; Spier et al. 2007), and some studies have reported improved vasodilatory capacity of the skeletal muscle vasculature following exercise training (Jendzjowsky and DeLorey 2012; Lash and Bohlen 1992; Martin et al. 1991; Thijssen et al. 2010); however, surprisingly little is known about the effect of exercise training on the neural control of circulation.

The control of blood pressure and skeletal muscle blood flow also appears to differ between men and women (Keir et al. 2020; Narkiewicz et al. 2005). Blood pressure and MSNA appear to be lower in young women than in men (Narkiewicz et al. 2005). However, females experience a larger increase in MSNA with aging compared with males (Keir et al. 2020; Narkiewicz et al. 2005), and the female vasculature may also become more responsive to sympathetic outflow with aging (Fadel et al. 2004; Narkiewicz et al. 2005). Consistent with these changes in vascular function, women are at an increased risk of developing hypertension and other CV diseases as they age (Burt et al. 1995). The mechanism(s) for the altered sympathetic control of vascular function in females remain to be determined, although circulating estrogen levels have been implicated (Fadel et al. 2003, 2004).

This review summarizes our current understanding of the modulatory effects of aging, exercise training, and sex on the control of sympathetic vasoconstriction in the skeletal muscle vascular bed at rest and during exercise, and identifies areas where additional research is needed. (Note: This review is based on the APNM President's Lecture delivered by the author at the Canadian Society for Exercise Physiology Annual Meeting 2019 and is not intended to be an exhaustive review of the literature in these areas.)

\section{Muscle sympathetic nerve activity}

MSNA is generated in the nuclei of the rostral ventrolateral medulla (RVLM) in the brainstem. Inputs from other regions of the brainstem, central nervous system, chemicals (e.g., angiotensin II, NO), and peripheral reflexes (e.g., baroreceptors and chemoreceptors) are integrated with the inherent activity of the RVLM to produce efferent sympathetic nerve activity (Dampney 1994). In humans and animals, MSNA occurs intermittently as bursts of impulses that are coupled to the diastolic phase of the cardiac cycle
(Hagbarth and Vallbo 1968; Johnson and Gilbey 1996; Sundlof and Wallin 1977). MSNA is typically quantified as burst frequency (bursts per unit time) and/or burst incidence (bursts per 100 heartbeats). The amount of activity is highly variable between individuals and changes in response to a variety of acute and chronic stimuli, including exercise. The amount and pattern of neural activity have been associated with the type and quantity of neurotransmitter release (Bradley et al. 2003; Johnson et al. 2001; Pernow et al. 1989). In particular, low discharge frequencies favour adenosine triphosphate (ATP) release followed by norepinephrine (NE), whereas mid-range discharge frequencies produce both ATP and NE release, and high discharge frequencies favour neuropeptide Y (NPY) release (Burnstock 2009; Pernow et al. 1989). NE binds to postsynaptic $\alpha_{1}$ - and $\alpha_{2}$-adrenergic receptors, and the non-adrenergic neurotransmitters ATP and NPY contribute to sympathetic vasoconstriction through binding with purinergic (P2X receptors) and NPY receptors on vascular smooth muscle (Buckwalter et al. 2003, 2005; Revington and McCloskey 1988).

\section{Aging}

Several studies have reported that resting efferent MSNA increases as a function of age in both men and women (Davy et al. 1998; Dinenno et al. 1999, 2000; Dinenno and Joyner 2006; Moreau et al. 2003; Ng et al. 1993). However, the mechanisms responsible for the increase in MSNA with advancing age have not yet been established. An increase in body and fat mass may contribute to an increase in sympathetic outflow with aging (Jones et al. 1997a, 1997b). Keir et al. (2020) recently reported that relatively modest increases in body mass index with aging contribute to the increase in MSNA with aging in both men and women. Indeed, MSNA has been shown to be markedly higher in obese than in non-obese adults, and loss of fat mass has been shown to decrease MSNA (Grassi et al. 2019; Costa et al. 2019).

Aging is also associated with an increase in sedentary behaviour and a decline in aerobic fitness (Blair et al., 1989; Diaz et al., 2016). Sympatho-excitation in response to activation of the RVLM was elevated in sedentary rats and blunted following exercise training, suggesting that exercise training/fitness may reduce central sympathetic outflow (Mueller 2007, 2010). Somewhat surprisingly, there is limited data on the effect of aerobic fitness on MSNA in older adults, and the available evidence is conflicting. In a study of middle-aged ( $\sim 45$ years of age) men, resting MSNA was not different between fit and sedentary participants (Notarius et al. 2012). In contrast, MSNA (burst frequency and burst incidence) was elevated in older (65+ years of age) endurance-trained male and female athletes compared with age-matched untrained controls ( $\mathrm{Ng}$ et al. 1994). Interestingly, the differences between athletes and untrained controls were primarily attributable to a marked increase in MSNA in endurance-trained compared with untrained females, raising the possibility that the effect of fitness on MSNA may differ between men and post-menopausal women (Ng et al.1994).

To date, no direct measurements of sympathetic nerve activity to exercising muscles have been performed in older animals or humans. Thus, our understanding of how aging affects the MSNA response to exercise is based on a limited number of studies and measures of circulating catecholamines and norepinephrine (NE) spillover. Whole-body NE spillover did not differ between young and older men cycling at the same relative exercise intensity $(50 \%$ of peak oxygen uptake $\left(\dot{V} \mathrm{O}_{\text {2peak }}\right)$ ) (Mazzeo et al.1997). In agreement, leg NE spillover was not different between young and older men during cycling exercise at $60 \% \dot{V} \mathrm{O}_{2 \text { peak }}$ (Proctor et al. 2003b). Consistent with a similar level of sympathetic outflow, leg blood flow and vascular conductance were not different between young and older men while cycling at the same absolute work rates (20$100 \mathrm{~W}$ ) and at a matched oxygen uptake $(1.1 \mathrm{~L} / \mathrm{min})$ (Proctor et al. 2003b). Leg NE spillover was also similar in older and young 
endurance-trained men during mild and moderate-intensity cycle exercise, but was greater in older endurance-trained men during very-heavy-intensity cycle exercise (Proctor et al.1998).

In summary, aging appears to result in a marked increase in resting sympathetic nervous system activity. During exercise, sympathetic activity appears to be similar in young and older adults; however, sympathetic outflow may be increased in older adults during very-heavy-intensity exercise. Further investigation is required to determine the effect of aging on sympathetic outflow during dynamic whole-body exercise and the potential interactions between the effects of age, sex, and fitness on MSNA.

\section{Exercise training}

Aerobic exercise training/fitness is associated with a decrease in CV disease risk, and exercise training is viewed as a therapeutic intervention in individuals with established CV disease (Blair et al. 1989). A decline in sympathetic nervous system activity resulting in a decrease in vascular resistance and arterial blood pressure may contribute to a reduction in disease risk in exercisetrained individuals (Joyner and Green 2009).

Exercise training has consistently been shown to reduce renal sympathetic nerve activity (RSNA) in experimental animals (Gao et al. 2007; Liu et al. 2000). Unfortunately, studies that have investigated the effect of exercise training and aerobic fitness on sympathetic nervous system outflow and/or plasma catecholamines in humans have produced conflicting results. Cross-sectional studies comparing untrained young adults with endurance-trained athletes have reported no difference in resting MSNA burst frequency and burst incidence between groups (Seals 1991; Svedenhag et al. 1984) or that aerobically trained adults had elevated levels of resting MSNA compared with age- and weight-matched sedentary adults (Alvarez et al. 2005; Ng et al. 1993).

Four weeks of cycle training at $70 \%$ of maximum heart rate did not change resting MSNA in young men (Cooke et al. 2002). Similarly, resting MSNA was unchanged in young men after 8 weeks of cycling at $75 \%$ maximal oxygen uptake and 12 weeks of cycle and run training at $75 \%$ peak heart rate did not alter MSNA in middle-aged men (Sheldahl et al. 1994; Svedenhag et al. 1984). Several studies have also reported that resting plasma NE concentrations remained unchanged after endurance exercise training (Peronn et al. 1981; Winder et al. 1978, 1979). In contrast, Grassi et al. (1994) reported that 10 weeks of run training (5 d/week) reduced resting MSNA in young men. Recently, Ehlers et al. (2020) reported that 6 weeks of high-intensity interval training on a cycle ergometer reduced resting MSNA in hypertensive and normotensive older men.

The effect of exercise training/aerobic fitness on the MSNA response to acute exercise is also unclear. Experiments that have measured MSNA in an inactive muscle during isolated small muscle mass exercise have provided some insight into the effects of exercise training/fitness on MSNA during exercise. However, given the small muscle mass activated during exercise, it is unclear whether these experiments are representative of whole-body dynamic exercise. Several cross-sectional studies have reported that the increase in MSNA in response to handgrip exercise did not differ between exercise-trained and untrained adults, suggesting that exercise training does not alter the MSNA response to exercise $(\mathrm{Ng}$ et al. 1994; Seals 1991; Sheldahl et al. 1994). However, prospective training studies have produced contrasting results. Unilateral forearm exercise training has been shown to attenuate the increase in MSNA and NE spillover in response to both non-fatiguing (25\% MVC) rhythmic forearm exercise and isometric handgrip exercise (Sinoway et al. 1996; Somers et al.1992). In agreement, Ray (1999) reported that the increase in MSNA during single-leg knee extension exercise was attenuated following 6 weeks of 1-legged cycle exercise training.

Collectively, the available evidence, although not conclusive, suggests that exercise training/aerobic fitness does not alter resting sympathetic outflow in young healthy adults. The effects of exercise training on the MSNA response to exercise are also unclear; however, the available prospective training studies suggest that exercise training may blunt the MSNA response to exercise. Further investigation in this area is required to determine the effect of training duration, intensity, and frequency on resting MSNA and the regulation of MSNA in response to large muscle mass dynamic exercise.

\section{Sex}

Compared with men, young women appear to have lower MSNA, lower resting blood pressure, and a reduced risk of CV disease (Baker et al. 2016; Hart and Charkoudian 2014; Maranon and Reckelhoff 2013, Narkiewicz et al. 2005). MSNA appears to rise at approximately age 30 in both sexes, with the increase in MSNA being steeper in women than in men (Keir et al. 2020). Indeed, the increase in MSNA per decade of life has been reported to be $\sim 3 \times$ greater in women than in men (Narkiewicz et al. 2005). These findings suggest that the sympathetic nervous system may play a progressively increasing role in the control of skeletal muscle vascular resistance with advancing age in women (Tank 2005). The mechanism(s) responsible for differences in MSNA between young men and women and the larger age-associated increase in MSNA in women compared with men have not been fully elucidated; however, a potential explanation may be differences in reproductive hormones. Estrogen receptors are expressed in multiple central nuclei that are responsible for basal and reflex activation of the sympathetic nervous system, and exposure to estradiol has been shown to blunt efferent sympathetic outflow, indicating that estrogen has an inhibitory effect on sympathetic nervous system activity (Saleh et al. 2000; Saleh and Connell 2007). Estrogen also upregulates the expression of NO synthase (NOS) in the brainstem, and NO has inhibitory effects on MSNA (Ceccatelli 1997; Ceccatelli et al. 1996; Owlya et al. 1997). Thus, estrogen may blunt efferent sympathetic outflow in a receptor-dependent and receptor-independent manner. Consistent with the central sympatho-inhibitory effect of estrogen, estradiol supplementation has been shown to reduce MSNA in postmenopausal women (Vongpatanasin et al. 2001). However, whether an age-related decline in estrogen bioavailability is responsible for the accelerated increase in resting MSNA with aging in women compared with men is less clear. Matsukawa et al. (1998) reported an age-dependent increase in resting MSNA in both men and women and indicated that the increase in resting MSNA in women was accelerated coincident with the onset of menopause. Narkiewicz et al. (2005) also reported a progressive increase in resting MSNA with aging in men and women, but concluded that the age-associated increase in MSNA in women occurred independently of menopausal status. Recently, Keir et al. (2020) reported that MSNA progressively increased in women and men beginning at $\sim 30$ years of age and argued that the increase in MSNA well in advance of the age ( $\sim 50 \mathrm{yrs}$ ) at which menopause typically begins, suggested that a decline in estrogen was not the primary mechanism responsible for the progressive increase in MSNA in women.

An attenuated MSNA response to static handgrip exercise has been reported in women compared with men, suggesting that sex may also influence the MSNA response to exercise (Ettinger et al. 1996; Jarvis et al. 2011). The mechanism(s) responsible for sex differences in the MSNA response to exercise have not been identified, but may include differences in muscle mass, fibre types and distribution, and sensitivity of the metabo- and mechano-reflexes between men and women (Ettinger et al. 1996), as well as cyclical changes in reproductive hormones throughout the menstrual cycle in women (Carter et al. 2013; Ettinger et al. 1998; Minson et al. 2000). Indeed, Ettinger et al. (1998) reported that the increase in MSNA during static handgrip exercise at $30 \%$ of maximal voluntary contraction (MVC) was smaller during the late than in the early follicular phase of the menstrual cycle, suggesting that high estrogen levels may blunt the 
MSNA response to exercise. However, in a subsequent study, a similar increase in MSNA in response to static handgrip exercise at $40 \%$ of MVC was observed during the luteal and follicular phases of the menstrual cycle, suggesting that cyclical changes in reproductive hormones may not alter the MSNA response to exercise in premenopausal women (Jarvis et al. 2011).

Overall, the available studies indicate that resting MSNA is lower in young women than in men. Resting MSNA increases as a function of age in both men and women, with the rate of increase in MSNA being substantially greater in women, whereas the MSNA response to exercise appears to be blunted in young women compared with men. Estrogen has been shown to blunt MSNA; however, the mechanism(s) responsible for sex differences in the regulation of efferent MSNA appear to be multifactorial and include differences in reproductive hormones, body and fat mass, and sensitivity of cardiovascular reflexes.

\section{Sympathetic vasoconstriction in resting skeletal muscle}

The functional consequence of efferent MSNA in the peripheral vasculature is vasoconstriction. Skeletal muscle is one of the largest vascular beds in the body, and regulation of vascular resistance in the skeletal muscle vascular bed is of paramount importance to the regulation of total peripheral resistance, the distribution of cardiac output and muscle blood flow, and the control of systemic blood pressure at rest and during exercise. It is well established that the sympathetic nervous system produces tonic vasoconstriction in the vasculature of resting skeletal muscles (Rowell 1993). The magnitude of tonic vasoconstriction in resting skeletal muscle is a function of sympathetic innervation, MSNA, and the responsiveness, density, and distribution of postsynaptic sympathetic receptors (Thomas and Segal 2004).

\section{Aging}

Whether aging is associated with elevated tonic sympathetic nervous system-mediated vasoconstriction is an unresolved issue. Age-associated increases in the amount and alterations in the pattern of MSNA may predispose older adults to a greater magnitude of adrenergic and non-adrenergic receptor-mediated sympathetic vasoconstriction. In older men compared with young men, non-selective $\alpha$-adrenergic receptor blockade produced a smaller increase in forearm blood flow, despite evidence of greater plasma NE concentrations in older than in young men, suggesting that tonic $\alpha$-adrenergic receptor-mediated vasoconstriction was reduced with aging (Dinenno et al. 2002). In contrast, non-selective $\alpha$-adrenergic blockade resulted in a proportionally larger increase in resting leg blood flow and vascular conductance in older men than in young men, suggesting elevated $\alpha$-adrenergic vasoconstriction in older men (Dinenno et al. 2001a, 2001b). Furthermore, leg vascular conductance remained approximately $25 \%$ lower in older men than in young men in the presence of $\alpha$-adrenergic blockade, suggesting that non-adrenergic receptormediated vasoconstriction may also be elevated with advancing age (Dinenno et al. 2001b). In a canine model of aging, the magnitude of $\alpha_{1}$ - and $\alpha_{2}$-adrenergic receptor-mediated restraint of resting skeletal muscle blood flow did not differ between old and young beagles (DeLorey et al. 2010). However, the magnitude of P2X receptormediated vasoconstriction was greater in old than in young beagles, whereas the magnitude of NPY-Y1 receptor-mediated restraint of skeletal muscle blood flow was reduced in old beagles at rest, suggesting that the relative contribution of non-adrenergic receptors to overall sympathetic vasoconstriction under basal conditions was altered as a function of advancing age (DeLorey et al. 2010). Overall, the available evidence is conflicting and differences in the limb/vascular bed studied and species differences make it difficult to draw a definitive conclusion on the effect of aging on tonic sympathetic vasoconstriction in the skeletal muscle vascular bed.

The responsiveness of post-synaptic sympathetic receptors may also influence the magnitude of sympathetic vasoconstriction, independent of efferent MSNA. In aged rodents, studies have reported reduced (Delp et al.1995; Sullivan and Davison 2001), unchanged (Bearden et al. 2004; Cook et al. 1992; Muller-Delp et al. 2002), or increased (Donato et al. 2007) $\alpha$-adrenergic receptor responsiveness. Donato et al. (2007) reported increased NEmediated vasoconstriction in first-order arterioles isolated from the soleus muscle of old rats, whereas vascular responsiveness to NE in vessels isolated from the gastrocnemius muscle was not affected by aging. Infusion of selective $\alpha_{1}$ - and $\alpha_{2}$-agonists produced similar decreases in skeletal muscle vascular conductance at rest in old and young beagles, suggesting that $\alpha$-adrenergic receptor responsiveness was not affected by aging (DeLorey et al. 2012). In humans, tyramine infusion resulted in a smaller decrease in resting forearm vascular conductance in older men than in young men, suggesting that aging blunts $\alpha$-adrenergic receptor responsiveness in men (Dinenno et al. 2002). Similarly, infusion of tyramine and selective $\alpha$-adrenergic agonists produced a smaller decrease in resting leg vascular conductance in older men than in young men (Smith et al. 2007), and phenylephrine-induced vasoconstriction was reduced in the resting leg of older men compared with young men (Wray et al. 2009).

The vascular response to sympathetic neurotransmitters and the infusion of selective agonists may also be affected by age-associated changes in receptor protein expression. In beagle gracilis-muscle feed arteries, $\alpha_{1 \mathrm{D}}$ and $\alpha_{2 \mathrm{~A}}$ adrenergic receptor protein expression was not affected by aging, whereas $\alpha_{1 \mathrm{~B}}$ adrenergic receptor protein expression was elevated in old compared with young beagles (DeLorey et al. 2012). The expression of P2X and NPY-Y1 non-adrenergic receptors did not differ between young and old beagles (DeLorey et al. 2012). Overall, these data suggest that aging differentially affects the expression of post-synaptic sympathetic receptors in a species, vascular bed, and vessel type-dependent manner. Further investigation is required to determine the effect of aging on post-synaptic receptor expression and distribution and how receptor expression interacts with MSNA and receptor responsiveness to regulate skeletal muscle blood flow.

\section{Exercise training}

In addition to effects on efferent MSNA, exercise training may modulate the magnitude of sympathetic vasoconstriction through effects on post-synaptic sympathetic receptor responsiveness and expression/distribution of sympathetic receptors. Following a 3-month aerobic exercise training intervention in middle-aged and older adults, non-selective $\alpha$-adrenergic receptor blockade produced a larger increase in leg vascular conductance, suggesting that exercise training augmented tonic $\alpha$-adrenergic receptor-mediated vasoconstriction in resting skeletal muscle (Sugawara et al. 2007). Whether elevated vasoconstriction was a function of increased MSNA or augmented $\alpha$-adrenergic receptor responsiveness after training was not established. However, chronic exercise training has been shown to alter the responsiveness of postsynaptic receptors to sympathetic stimuli (Lash 1998; McAllister and Laughlin 1997; Wiegman et al. 1981). The vasoconstrictor response to NE was enhanced in rat spinotrapezius muscle first-order arterioles following 10 weeks of treadmill training (Lash 1998) and after 7 days of treadmill exercise in the femoral and brachial arteries of miniature swine (McAllister and Laughlin 1997). In contrast, the vasoconstrictor response to $\mathrm{NE}$ was decreased in rat cremaster arterioles after 6 weeks of swim training (Wiegman et al. 1981) and unchanged in arterioles from rat gracilis and soleus muscle after 10-12 weeks of heavy-intensity treadmill exercise training, or 4 weeks of mildintensity treadmill exercise, respectively (Jasperse and Laughlin 1999; Sun et al. 1994). Collectively, the data from studies in isolated blood vessels demonstrate that exercise training may alter postsynaptic sympathetic receptor responsiveness; however, the effects of exercise training appear to be dependent on the muscle and vascular segment investigated and the exercise training stimulus applied. While in vitro data provide important information about the effects of exercise 
training on specific blood vessels, these studies may not be reflective of the effects of exercise training on the in vivo integrated regulation of the skeletal muscle resistance vasculature. To address this gap in the literature, my laboratory has used an in vivo anesthetized rat model and chronic exercise training to investigate the integrative control of sympathetic vasoconstriction in resting and contracting skeletal muscles. Jendzjowsky and DeLorey (2012, 2013d) demonstrated that exercise training augmented evoked sympathetic vasoconstriction in resting skeletal muscle in a training intensity-dependent manner. Both $\alpha_{1}$ - and $\alpha_{2}$-adrenergic receptormediated vasoconstrictor responses were augmented in resting skeletal muscle of exercise-trained rats compared with sedentary rats (Jendzjowsky and DeLorey 2013c; Just and DeLorey 2016). Increased sympathetic vasoconstrictor responsiveness was correlated with an increase in endothelium-dependent vasodilation, suggesting that training adaptations in sympathetic vasoconstriction may occur in an integrative manner with changes in local vasodilation to regulate vascular resistance and muscle blood flow (Just et al. 2016). Consistent with this notion, aerobic exercise training has been shown to produce parallel increases in endotheliumdependent vasodilation and tonic sympathetic vasoconstriction at rest in middle-aged and older adults (Sugawara et al. 2007). In contrast to training-mediated increases in sympathetic vasoconstrictor responsiveness, forearm vasoconstriction in response to lower body negative pressure has been shown to be lower in aerobically fit middle-aged men than in aged-matched sedentary men (Notarius et al. 2012). Lower body negative pressure evoked similar increases in MSNA in sedentary and aerobically fit men, suggesting that aerobic fitness blunts neurovascular coupling and/or postsynaptic sympathetic vasoconstrictor responsiveness (Notarius et al. 2012). The effect of exercise training on non-adrenergic receptor-mediated vasoconstriction has not yet been investigated. The effects of exercise training on the expression of postsynaptic sympathetic receptors are also largely unknown. Mortensen et al. (2014b) reported a small, but statistically significant, increase in skeletal muscle P2X receptor expression following 8 weeks of aerobic exercise training in middle-aged, normotensive men and women, suggesting that postsynaptic receptor expression may be responsive to exercise training. However, further investigation is required to determine the effect of exercise training on the full spectrum of postsynaptic sympathetic receptors and to determine the integrative effects of exercise training on post-synaptic receptor responsiveness, expression, and distribution.

\section{$\operatorname{Sex}$}

In addition to the effects on MSNA, sex may also influence the transduction of sympathetic activity into vasoconstriction in the skeletal muscle vascular bed and/or postsynaptic receptor responsiveness. Sympatho-excitation via the cold pressor test and isometric handgrip has been shown to produce similar increases in efferent MSNA, but smaller increases in calf vascular resistance in females than in males (Hogarth et al. 2007), suggesting that $\alpha$-adrenergic receptor responsiveness may be blunted in females compared with males. In agreement, Hart et al. (2009) observed that resting MSNA and total peripheral resistance (TPR) were positively correlated in young men, but not in women, further suggesting that sympathetic vasoconstrictor responsiveness and/or sympathetic vascular transduction may be blunted in women compared with men. In a subsequent study, MSNA and TPR were correlated in young women in the presence of $\beta$-adrenergic receptor blockade (Hart et al. 2011). Infusion of NE also produced a smaller constrictor response in the forearm of women compared with men, and sex differences in constrictor responses were abolished by $\beta$-adrenergic receptor blockade (Kneale et al. 2000). Taken together, these findings suggest that $\beta$-adrenergic receptor-mediated vasodilation may inhibit $\alpha$-adrenergic receptormediated vasoconstriction in females and contribute to sex differences in neurovascular coupling. However, intra-arterial infusion of selective $\alpha_{1^{-}}$and $\alpha_{2}$-adrenergic receptor agonists in the forearm produced a similar vasoconstriction in males and females, suggesting that sex does not alter $\alpha$-adrenergic receptor responsiveness (Limberg et al. 2010). In agreement, evoked vasoconstriction in the resting leg (via neck pressure and isometric handgrip) did not differ between men and women, and $\beta$-adrenergic receptor blockade did not alter vasoconstrictor responsiveness in either sex (Pellinger and Halliwill 2007). Cooper et al. (2021) also recently reported that $\beta$-adrenergic receptor blockade did not alter sympathetic vasoconstrictor responsiveness in the resting hindlimb of sedentary or exercise-trained female rats. Similar forearm vasodilation to isoproterenol ( $\beta$-adrenergic receptor agonist) has also been reported in males and females, suggesting that sex may not modulate $\beta$-adrenergic receptor responsiveness/function (Limberg et al. 2016). Just and DeLorey (2017) recently reported that non-selective NOS inhibition produced a similar increase in sympathetic vasoconstrictor responsiveness in the resting hindlimb of male and female rats, indicating that sex does not modulate NO-mediated inhibition of sympathetic vasoconstriction in resting skeletal muscle. Finally, selective NPY Y1 receptor blockade increased hindlimb vascular conductance in male rats, but produced no change in female rats, indicating that tonic NPY-mediated vasoconstriction was absent in resting skeletal muscle of female rats, suggesting that sex differences in non-adrenergic receptor-mediated vasoconstriction may contribute to differences in neurovascular transduction between males and females (Jackson et al. 2005).

The effect of sex on sympathetic vasoconstriction may also interact with age. Narkiewicz et al. (2005) reported that the increase in blood pressure per increment in MSNA is markedly greater in older women than in men, suggesting that older females may have an increased vascular responsiveness to sympathetic stimulation. Hart et al. (2011) have shown that $\beta$-adrenergic receptor blockade does not alter the relationship between MSNA and total peripheral resistance in postmenopausal women, suggesting that $\beta$-adrenergic receptor-mediated opposition to $\alpha$-adrenergic receptor-mediated vasoconstriction may be lost as women age. Moreover, postmenopausal women who received hormone replacement therapy (HRT) experienced no age-associated decline in basal leg blood flow (Moreau et al. 2003). Notably, HRT did not alter MSNA, suggesting that HRT restored leg blood flow through local vasodilation or greater inhibition of post-synaptic sympathetic receptors (Moreau et al. 2003). In contrast, a smaller decrease in leg vascular conductance in response to sympathetic stimulation (cold-pressor test) has been observed in older women than in men, suggesting a reduced vascular responsiveness to sympathetic stimulation in older women (Parker et al. 2007).

Further studies are necessary to partition the relative contributions of adrenergic and non-adrenergic neurotransmitters and receptors to sympathetic vasoconstriction in males and females to fully elucidate the effect of sex on sympathetic vascular control in the resting skeletal muscle vascular bed. Further investigation of the integrative effects of sex and aging on sympathetic vascular control is also warranted.

\section{Sympathetic vasoconstriction in contracting muscle and sympatholysis}

Exercise is characterized by an increase in cardiac output, arterial blood pressure, and skeletal muscle blood flow (Rowell 1993). Vasodilation in the skeletal muscle vascular bed facilitates an increase in muscle blood flow/oxygen delivery, which is closely matched to muscle metabolic demand (Delp 1999). Concomitantly, sympathetic nerve activity to both exercising and non-active tissues (DiCarlo et al. 1996; O’Hagan et al. 1993; Savard et al. 1987) increases to produce vasoconstriction, which opposes robust local vasodilation and maintains arterial blood pressure (Rowell 1993). Indeed, several studies have demonstrated that $\alpha$-adrenergic and non-adrenergic receptors tonically constrict the vasculature of exercising muscles even during intense and prolonged exercise (Buckwalter et al.1997, 2005; DeLorey et al. 2006, 2007; O'Leary et al. 1997). However, it is well established that muscular contraction blunts sympathetic 
vasoconstriction in the skeletal muscle vascular bed in an exercise intensity-dependent manner, a phenomenon known as sympatholysis (Buckwalter and Clifford 2001; DeLorey et al. 2002; Hansen et al. 2000; Remensnyder et al. 1962) . The overarching benefit of sympatholysis is the enhancement of local muscle blood flow $/ \mathrm{O}_{2}$ delivery while concomitantly maintaining systemic blood pressure during exercise. While the mechanism responsible for sympatholysis has not been definitively established, our present understanding is that a vasoactive molecule released from the endothelium, skeletal muscle, or possibly red blood cells may inhibit the release of sympathetic neurotransmitters or the responsiveness of postsynaptic sympathetic receptors (Just et al. 2016; Thomas and Segal 2004).

\section{Aging}

An age-related increase in MSNA may result in elevated tonic vasoconstriction and reduced skeletal muscle blood flow. To test the hypothesis that aging is associated with elevated sympathetic restraint of skeletal muscle blood flow during exercise, DeLorey et al. (2010) injected selective antagonists for $\alpha-1, \alpha-2$, NPY, and $\mathrm{P} 2 \mathrm{X}$ receptors into the hindlimb of young and old beagles during treadmill running at $2.5 \mathrm{mph}$ and $4 \mathrm{mph}$ with $2.5 \%$ grade. Selective blockade of adrenergic and non-adrenergic receptors produced similar increases in skeletal muscle vascular conductance in young and old beagles during exercise, indicating that the magnitude of tonic adrenergic and non-adrenergic receptor-mediated sympathetic vasoconstriction did not differ between young and old canines during treadmill running at the same absolute exercise intensity (DeLorey et al. 2010). Consistent with a similar magnitude of tonic vasoconstriction, injection of selective $\alpha_{1}$ - and $\alpha_{2}$-agonists produced similar decreases in skeletal muscle vasoconstriction during moderate- and heavy-intensity treadmill exercise in old and young beagles, suggesting that $\alpha$-adrenergic receptor responsiveness during exercise was not affected by aging (DeLorey et al. 2012). Similarly, Wray et al. (2009) reported a similar vasoconstrictor response to phenylephrine ( $\alpha_{1}$-adrenergic receptor agonist) in the legs of young and older men performing unilateral knee extension exercise at the same absolute exercise intensity. In contrast, Koch et al. (2003) reported a larger decrease in vascular conductance during cycle exercise with cold-pressor-initiated reflex-sympathetic vasoconstriction in older men than in young men, suggesting that vasoconstrictor responsiveness may be increased in aged men. Consistent with this notion, infusion of selective $\alpha$-adrenergic agonists also produced a larger decrease in vascular conductance in older men than in young men during leg cycling and handgrip exercise (Dinenno et al. 2005; Wray et al. 2009). Similarly, lower body negative pressure produced a larger decrease in vascular conductance during forearm contractions in older women than in young women (Fadel et al. 2004). Collectively, these data suggest that aging may be associated with diminished contraction-mediated inhibition of sympathetic vasoconstriction. While a definitive mechanism has not been identified, there is accumulating evidence that NO is involved in the blunting of sympathetic vasoconstriction (Chavoshan et al. 2002; Jendzjowsky and DeLorey 2013a, 2013b; Jendzjowsky et al. 2014b; Sander et al. 2000; Thomas and Victor 1998). Aging is associated with a decrease in endothelial NO synthase expression and NO bioavailability (Barton et al. 1997; Csiszar et al. 2002; Tanabe et al. 2003), and it has been argued that NO is completely inactivated in humans over 60 (Taddei et al. 2001). However, lifelong physical activity appears to maintain NO bioavailability and functional sympatholysis in older adults (Mortensen et al. 2012; Nyberg et al. 2012).

Aging may also affect the responsiveness of non-adrenergic receptors and contraction-mediated inhibition of non-adrenergic receptormediated vasoconstriction. Selective NPY and P2X receptor agonists produced similar vasoconstrictor responses in the hindlimb of young and old beagles during moderate- and heavy-intensity exercise, suggesting that aging does not alter non-adrenergic receptor responsiveness (DeLorey et al. 2012).
Intravascular infusion of exogenous ATP has also been shown to inhibit vasoconstriction (Hearon et al. 2017; Kirby et al. 2008, 2011; Mortensen et al. 2014a; Rosenmeier et al. 2004) and enhance sympatholysis in older men to levels comparable to those observed in young men (Kirby et al. 2011). Moreover, Kirby et al. (2012) have shown that plasma ATP was lower during handgrip exercise in older men than in young men, and that reduced ATP was associated with blunted exercise hyperemia in older men. A decline in intra-vascular ATP bioavailability with advancing age may impair ATP-mediated sympatholysis; however, it is presently unknown whether endogenously produced ATP blunts sympathetic vasoconstriction. Further investigation is necessary to establish the effect of aging on sympathetic vasoconstriction during exercise, particularly in humans, during large muscle mass dynamic exercise.

\section{Exercise training}

Exercise training may enhance sympatholysis and improve neural control of vascular resistance, the distribution of blood flow between and within skeletal muscles, and blood pressure during exercise. Indeed, studies in rodents and humans have demonstrated that aerobic exercise training enhances sympatholysis in a training intensity-dependent manner (Jendzjowsky and DeLorey 2013c, 2013d; Jendzjowsky et al. 2014a; Just and DeLorey 2016, Just et al. 2016; Mizuno et al. 2014; Mortensen et al. 2014b).

Selective $\alpha_{2}$-adrenergic receptor blockade reduced sympatholysis following heavy-intensity exercise training (Jendzjowsky and DeLorey 2013c). The decline in sympatholysis in the presence of selective $\alpha_{2}$-adrenergic receptor blockade suggests that the enhanced sympatholysis after heavy-intensity exercise training was partly attributable to an increased ability to inhibit $\alpha_{2}$-adrenergic receptormediated vasoconstriction (Jendzjowsky and DeLorey 2013c). However, sympatholysis remained greater in exercise-trained rats than in sedentary rats in the presence of selective $\alpha_{2}$-adrenergic receptor blockade, indicating that exercise training may also augment contraction-mediated inhibition of $\alpha_{1}$-adrenergic or non-adrenergic receptor-mediated vasoconstriction (Jendzjowsky and DeLorey 2013c). In a subsequent study, selective $\alpha_{1}$-adrenergic receptor blockade abolished exercise training-induced improvements in sympatholysis, demonstrating that exercise training augmented contractionmediated blunting of $\alpha_{1}$-adrenergic receptor-mediated vasoconstriction (Just and DeLorey 2016). Collectively, these data indicate that the relative contributions of $\alpha_{1}$ - and $\alpha_{2}$-adrenergic receptors to evoked vasoconstrictor responses are altered following exercise training, and that $\alpha$-adrenergic receptors become more susceptible to inhibition during contraction after aerobic exercise training (Jendzjowsky and DeLorey 2013c; Just and DeLorey 2016).

Exercise training also appears to augment NO-mediated sympatholysis, as evidenced by a marked reduction in sympatholysis in exercise-trained rats following pharmacological blockade of NOS (Jendzjowsky and DeLorey 2013d; Jendzjowsky et al. 2014a; Mizuno et al. 2014). The cellular mechanism of NO-mediated sympatholysis has not been identified; however, NO has been shown to inhibit both $\alpha_{1}$-and $\alpha_{2}$-adrenergic receptor-mediated vasoconstriction in isolated arteries (Ohyanagi et al. 1992). In the presence of selective $\alpha_{2}$-adrenergic receptor blockade, NOS inhibition reduced the magnitude of sympatholysis in heavy-intensity exercise-trained rats, suggesting that exercise training enhanced NO-mediated inhibition of $\alpha_{1}$-adrenergic receptor- or non-adrenergic receptor-mediated vasoconstriction (Jendzjowsky and DeLorey 2013c). Consistent with this interpretation, NOS inhibition in the presence of selective $\alpha_{1}$-adrenergic receptor blockade did not alter sympatholysis in sedentary or exercise-trained rats, suggesting that functional $\alpha_{1}$-adrenergic receptors are required for NO-dependent sympatholysis (Just and DeLorey 2016). Similar findings have been reported in untrained dogs, where NOS inhibition abolished contraction-mediated 
inhibition of $\alpha_{1}$-adrenergic receptors but did not change the blunting of $\alpha_{2}$-adrenergic receptor-mediated vasoconstriction during exercise (Buckwalter et al. 2004). Collectively, these data suggest that the primary mechanism responsible for enhanced sympatholysis following exercise training is augmented NO-dependent inhibition of $\alpha_{1}$-adrenergic receptors (Jendzjowsky and DeLorey 2013c; Just and DeLorey 2016).

NO derived from both endothelial NOS (eNOS) and neuronal NOS (nNOS) has been shown to inhibit vasoconstriction during exercise in sedentary and exercise-trained rats (Jendzjowsky and DeLorey 2013b; Jendzjowsky et al. 2014a). Exercise training appears to upregulate nNOS-mediated inhibition of vasoconstriction in contracting skeletal muscle (Jendzjowsky et al. 2014a), and selective nNOS blockade has been shown to abolish the enhanced sympatholysis in exercise-trained rats (Just et al. 2016). Consistent with enhanced nNOS-mediated vascular function, skeletal muscle nNOS expression was greater in exercise-trained rats than in sedentary rats (Jendzjowsky et al. 2014a). The traininginduced increase in nNOS expression was predominately in muscle with a high proportion of type II, fast-twitch, glycolytic muscle fibres, suggesting that exercise training may enhance NO-mediated sympatholysis in a fibre-type dependent manner (Jendzjowsky et al. 2014a). Further research is required to establish how exercise training may alter sympatholysis in specific skeletal muscle fibre types.

\section{Sex}

Sex differences in the regulation of sympathetic vasoconstrictor responsiveness and sympatholysis have received relatively little attention in the scientific literature. Limberg et al. (2010) reported that intraarterial infusion of selective $\alpha_{1}$ and $\alpha_{2}$-adrenergic receptor agonists produced a similar vasoconstriction in the forearm of men and women during handgrip exercise, suggesting that $\alpha$-adrenoreceptor responsiveness and contraction-mediated inhibition of vasoconstriction were not different between sexes. In rats, sympathetic vasoconstrictor responsiveness during contraction was lower in females than in males, and sympatholysis was enhanced in female rats (Just and DeLorey 2017). A portion of the enhanced sympatholysis in female rats was NO-dependent, as non-selective NOS inhibition reduced sympatholysis in female rats (Just and DeLorey 2017) . However, sympatholysis remained greater in female rats than in male rats in the presence of NOS inhibition, suggesting that other mechanisms also contribute to sex differences in contraction-mediated inhibition of vasoconstriction (Just and DeLorey 2017). Cooper et al. (2021) recently investigated whether $\beta$-adrenergic receptor-mediated opposition of sympathetic vasoconstriction may be augmented in female rats compared with male rats and contribute to enhanced sympatholysis in female rats. Consistent with the findings of Just and DeLorey (Just and DeLorey 2017), sympatholysis was greater in females than in male rats; however, $\beta$-adrenergic receptor blockade did not augment sympatholysis in male or female rats, indicating that $\beta$-adrenergic receptors do not oppose sympathetic vasoconstriction and that $\beta$-adrenergic receptormediated blunting of sympathetic vasoconstriction does not contribute to enhanced sympatholysis in female rats (Cooper et al. 2021).

A reduction in sympatholysis has been reported in ovariectomized rats and post-menopausal women, and acute estrogen supplementation/therapy restored sympatholysis, suggesting that estrogen may contribute to sex differences in sympatholysis (Fadel et al. 2003, 2004). However, similar blunting of $\alpha_{1^{-}}$and $\alpha_{2}$-adrenergic receptor-mediated vasoconstriction during handgrip exercise in the luteal and follicular phases of the menstrual cycle has also been reported (Limberg et al. 2010). Further research is required to clarify the role of estrogen in the regulation of sympatholysis and to elucidate the mechanism by which females are better able to blunt sympathetic vasoconstriction in the skeletal muscle vascular bed during exercise.

\section{Summary}

This review has demonstrated that aging, exercise training, and sex modulate the control of sympathetic vasoconstriction in the skeletal muscle vascular bed at rest and during exercise. The available literature also reveals a fundamental lack of understanding of the mechanisms responsible for the effects of aging, exercise training, and sex on the control of the skeletal muscle vasculature. Exercise training is often viewed as a primary prevention and treatment for age-related vascular dysfunction and is associated with reduced CV morbidity and mortality (Blair et al. 1989). However, our understanding of the adaptive mechanisms of this protection is limited. In addition to a lack of understanding of the basic physiological changes resulting from exercise training, our understanding of the exercise prescription (intensity, frequency, and duration) that will produce the maximum reduction in $\mathrm{CV}$ disease risk and maximum improvement in physiological function is limited. Almost no attention has been directed to the examination of the dose-response relationship between exercise training and vascular health, particularly in women.

Unraveling the independent and interdependent effects of aging, sex, and exercise training on neurovascular control is particularly important, as several age-related chronic diseases (e.g., heart failure, hypertension, and metabolic syndrome) are characterized by elevated sympathetic outflow, diminished vascular function, decreased NO bioavailability, and exercise intolerance (Blair et al. 1989; Carter and Ray 2015; Paterson et al. 2004, 2007; Taddei et al. 2001).

\section{Conflict of interest statement}

The author has no conflicts to report.

\section{Acknowledgements}

This work was supported by grants from the Natural Sciences and Engineering Research Council of Canada and the Canadian Foundation for Innovation. The author would like to acknowledge the editorial assistance of Breanne Collison and the contributions of all past and present lab members to the projects presented in this review.

\section{References}

Alvarez, G.E., Halliwill, J.R., Ballard, T.P., Beske, S.D., and Davy, K.P. 2005. Sympathetic neural regulation in endurance-trained humans: fitness vs. fatness. J. Appl. Physiol. (1985), 98(2): 498-502. doi:10.1152/japplphysiol.01020.2004. PMID:15489260.

Baker, S.E., Limberg, J.K., Ranadive, S.M., and Joyner, M.J. 2016. Neurovascular control of blood pressure is influenced by aging, sex, and sex hormones. Am. J. Physiol. Regul. Integr. Comp. Physiol. 311(6): R1271-R1275. doi:10.1152/ajpregu.00288.2016. PMID:27856414.

Barton, M., Cosentino, F., Brandes, R.P., Moreau, P., Shaw, S., and LüScher, T.F. 1997. Anatomic heterogeneity of vascular aging: role of nitric oxide and endothelin. Hypertension, 30((4): 817-824. doi:10.1161/01.HYP.30.4.817. PMID:9336378.

Bearden, S.E., Payne, G.W., Chisty, A., and Segal, S.S. 2004. Arteriolar network architecture and vasomotor function with ageing in mouse gluteus maximus muscle. J. Physiol. 561(Pt 2): 535-545. doi:10.1113/jphysiol.2004. 068262. PMID:15388783.

Beere, P.A., Russell, S.D., Morey, M.C., Kitzman, D.W., and Higginbotham, M.B. 1999. Aerobic exercise training can reverse age-related peripheral circulatory changes in healthy older men. Circulation, 100(10): 1085-1094. doi:10.1161/01. cir.100.10.1085. PMID:10477534.

Blair, S.N., Kohl, H.W, 3rd., Paffenbarger, R.S, Jr., Clark, D.G., Cooper, K.H., and Gibbons, L.W. 1989. Physical fitness and all-cause mortality. A prospective study of healthy men and women. JAMA, 262(17): 2395-2401. doi:10.1001/jama.262.17.2395. PMID:2795824.

Bradley, E., Law, A., Bell, D., and Johnson, C.D. 2003. Effects of varying impulse number on cotransmitter contributions to sympathetic vasoconstriction in rat tail artery. Am. J. Physiol. Heart Circ. Physiol. 284(6): H2007-H2014. doi:10.1152/ajpheart.01061.2002. PMID:12742824.

Buckwalter, J.B., and Clifford, P.S. 2001. The paradox of sympathetic vasoconstriction in exercising skeletal muscle. Exerc. Sport Sci. Rev. 29(4): 159-163. doi:10.1097/00003677-200110000-00005. PMID:11688788. 
Buckwalter, J.B., Mueller, P.J., and Clifford, P.S. 1997. Sympathetic vasoconstriction in active skeletal muscles during dynamic exercise. J. Appl. Physiol. (1985). 83(5): 1575-1580. doi:10.1152/jappl.1997.83.5.1575. PMID:9375322.

Buckwalter, J.B., Hamann, J.J., and Clifford, P.S. 2003. Vasoconstriction in active skeletal muscles: a potential role for P2X purinergic receptors? J. Appl. Physiol. (1985), 95(3): 953-959. doi:10.1152/japplphysiol.00173.2003. PMID:12766177.

Buckwalter, J.B., Taylor, J.C., Hamann, J.J., and Clifford, P.S. 2004. Role of nitric oxide in exercise sympatholysis. J. Appl. Physiol. (1985). 97(1): 417423. doi:10.1152/japplphysiol.01181.2003. PMID:15020577.

Buckwalter, J.B., Hamann, J.J., and Clifford, P.S. 2005. Neuropeptide Y1 receptor vasoconstriction in exercising canine skeletal muscles. J. Appl. Physiol. 99(6): 2115-2120. doi:10.1152/japplphysiol.00427.2005. PMID:16099895.

Burnstock, G. 2009. Autonomic neurotransmission: 60 years since Sir Henry Dale. Annu. Rev. Pharmacol. Toxicol. 49: 1-30. doi:10.1146/annurev.pharmtox. 052808.102215. PMID:18834312.

Burt, V.L., Whelton, P., Roccella, E.J., Brown, C., Cutler, J.A., Higgins, M., et al. 1995. Prevalence of hypertension in the US adult population. Results from the Third National Health and Nutrition Examination Survey, 1988-1991. Hypertension, 25(3): 305-313. doi:10.1161/01.HYP.25.3.305. PMID:7875754.

Carter, J.R., and Ray, C.A. 2015. Sympathetic neural adaptations to exercise training in humans. Auton. Neurosci. 188: 36-43. doi:10.1016/j.autneu.2014. 10.020. PMID:25458425.

Carter, J.R., Fu, Q., Minson, C.T., and Joyner, M.J. 2013. Ovarian cycle and sympathoexcitation in premenopausal women. Hypertension, 61(2): 395399. doi:10.1161/HYPERTENSIONAHA.112.202598. PMID:23172932.

Ceccatelli, S. 1997. Expression and plasticity of NO synthase in the neuroendocrine system. Brain Res. Bull. 44(4): 533-538. doi:10.1016/s0361-9230(97) 00239-6. PMID:9370221.

Ceccatelli, S., Grandison, L., Scott, R.E., Pfaff, D.W., and Kow, L.M. 1996. Estradiol regulation of nitric oxide synthase mRNAs in rat hypothalamus. Neuroendocrinology, 64(5): 357-363. doi:10.1159/000127139. PMID:8930936.

Chavoshan, B., Sander, M., Sybert, T.E., Hansen, J., Victor, R.G., and Thomas, G.D. 2002. Nitric oxide-dependent modulation of sympathetic neural control of oxygenation in exercising human skeletal muscle. J. Physiol. (Lond.), 540(1): 377386. doi:10.1113/jphysiol.2001.013153. PMID:11927694.

Cook, J.J., Wailgum, T.D., Vasthare, U.S., Mayrovitz, H.N., and Tuma, R.F. 1992. Age-related alterations in the arterial microvasculature of skeletal muscle. J. Gerontol. 47(3): B83-8. doi:10.1093/geronj/47.3.B83. PMID:1573183.

Cooke, W.H., Reynolds, B.V., Yandl, M.G., Carter, J.R., Tahvanainen, K.U., and Kuusela, T.A. 2002. Effects of exercise training on cardiovagal and sympathetic responses to Valsalva's maneuver. Med. Sci. Sports Exerc. 34(6): 928-935. doi:10.1097/00005768-200206000-00004. PMID:12048317.

Cooper, I.R., Liu, S., and DeLorey, D.S. 2021. Effects of sex and exercise training on $\beta$-adrenoreceptor-mediated opposition of evoked sympathetic vasoconstriction in resting and contracting muscle of rats. J. Appl. Physiol. (1985), 130(1): 114-123. doi:10.1152/japplphysiol.00726.2020. PMID:33090912.

Costa, J., Moreira, A., Moreira, P., Delgado, L., and Silva, D. 2019. Effects of weight changes in the autonomic nervous system: A systematic review and meta-analysis. Clin. Nutr. 38(1): 110-126. doi:10.1016/j.clnu.2018.01.006. PMID:29395374

Csiszar, A., Ungvari, Z., Edwards, J.G., Kaminski, P., Wolin, M.S., Koller, A., and Kaley, G. 2002. Aging-induced phenotypic changes and oxidative stress impair coronary arteriolar function. Circ. Res. 90(11): 1159-1166. doi:10.1161/01.res.0000020401.61826.ea. PMID:12065318.

Dampney, R.A. 1994. Functional organization of central pathways regulating the cardiovascular system. Physiol. Rev. 74(2): 323-364. doi:10.1152/physrev. 1994.74.2.323. PMID:8171117.

Davy, K.P., Seals, D.R., and Tanaka, H. 1998. Augmented cardiopulmonary and integrative sympathetic baroreflexes but attenuated peripheral vasoconstriction with age. Hypertension, 32(2): 298-304. doi:10.1161/01.HYP.32.2.298.

DeLorey, D.S., Wang, S.S., and Shoemaker, J.K. 2002. Evidence for sympatholysis at the onset of forearm exercise. J. Appl. Physiol. 93(2): 555-560. doi:10.1152/japplphysiol.00245.2002. PMID:12133864.

DeLorey, D.S., Hamann, J.J., Kluess, H.A., Clifford, P.S., and Buckwalter, J.B. 2006. Alpha-adrenergic receptor mediated restraint of skeletal muscle blood flow during prolonged exercise. J. Appl. Physiol. 100(5): 1563-1568. doi:10.1152/japplphysiol.01035.2005. PMID:16410381.

DeLorey, D.S., Hamann, J.J., Valic, Z., Kluess, H.A., Clifford, P.S., and Buckwalter, J.B. 2007. Alpha-Adrenergic receptor responsiveness is preserved during prolonged exercise. Am. J. Physiol. Heart Circ. Physiol. 292(1): H392-8. doi:10.1152/ajpheart. 00787.2006. PMID:16951042.

DeLorey, D.S., Buckwalter, J.B., Mittelstadt, S.W., Anton, M.M., Kluess, H.A., and Clifford, P.S. 2010. Is tonic sympathetic vasoconstriction increased in the skeletal muscle vasculature of aged canines? Am. J. Physiol. Regul. Integr. Comp. Physiol. 299(5): R1342-9. doi:10.1152/ajpregu.00194.2010. PMID:20702803.

DeLorey, D.S., Clifford, P.S., Mittelstadt, S., Anton, M.M., Kluess, H.A., Tune, J.D., et al. 2012. The effect of aging on adrenergic and nonadrenergic receptor expression and responsiveness in canine skeletal muscle. J. Appl. Physiol. 112(5): 841-848. doi:10.1152/japplphysiol.00945.2011. PMID:22194325.

Delp, M.D. 1999. Control of skeletal muscle perfusion at the onset of dynamic exercise. Med. Sci. Sports Exerc. 31(7): 1011-1018. PMID:10416563.
Delp, M.D., Brown, M., Laughlin, M.H., and Hasser, E.M. 1995. Rat aortic vasoreactivity is altered by old age and hindlimb unloading. J. Appl. Physiol. (1985), 78(6): 2079-2086. doi:10.1152/jappl.1995.78.6.2079. PMID:7665402.

Diaz, K.M., Howard, V.J., Hutto, B., Colabianchi, N., Vena, J.E., Blair, S.N., and Hooker, S.P. 2016. Patterns of sedentary behavior in US middle-age and older adults: The REGARDS Study. Med. Sci. Sports Exerc. 48(3): 430438. doi:10.1249/MSS.0000000000000792. PMID:26460633.

DiCarlo, S.E., Chen, C.Y., and Collins, H.L. 1996. Onset of exercise increases lumbar sympathetic nerve activity in rats. Med. Sci. Sports Exerc. 28(6): 677-684. doi:10.1097/00005768-199606000-00006. PMID:8784755.

Dinenno, F.A., and Joyner, M.J. 2006. Alpha-adrenergic control of skeletal muscle circulation at rest and during exercise in aging humans. Microcirculation, 13(4): 329-341. doi:10.1080/10739680600618843. PMID:16611594.

Dinenno, F.A., Jones, P.P., Seals, D.R., and Tanaka, H. 1999. Limb blood flow and vascular conductance are reduced with age in healthy humans: relation to elevations in sympathetic nerve activity and declines in oxygen demand. Circulation, 100(2): 164-170. doi:10.1161/01.CIR.100.2.164. PMID:10402446.

Dinenno, F.A., Jones, P.P., Seals, D.R., and Tanaka, H. 2000. Age-associated arterial wall thickening is related to elevations in sympathetic activity in healthy humans. Am. J. Physiol. Heart Circ. Physiol. 278(4): H1205-10. doi:10.1152/ajpheart.2000.278.4.H1205. PMID:10749715.

Dinenno, F.A., Seals, D.R., Desouza, C.A., and Tanaka, H. 2001a. Age-related decreases in basal limb blood flow in humans: time course, determinants and habitual exercise effects. J. Physiol. 531(Pt 2): 573-579. doi:10.1111/ j.1469-7793.2001.0573i.x. PMID:11230528.

Dinenno, F.A., Tanaka, H., Stauffer, B.L., and Seals, D.R. 2001b. Reductions in basal limb blood flow and vascular conductance with human ageing: role for augmented alpha-adrenergic vasoconstriction. J. Physiol. 536(Pt 3): 977-983. doi:10.1111/j.1469-7793.2001.00977.x. PMID:11691889.

Dinenno, F.A., Dietz, N.M., and Joyner, M.J. 2002. Aging and forearm postjunctional alpha-adrenergic vasoconstriction in healthy men. Circulation, 106(11): 1349-1354. doi:10.1161/01.CIR.0000028819.64790.BE. PMID:12221051.

Dinenno, F.A., Masuki, S., and Joyner, M.J. 2005. Impaired modulation of sympathetic alpha-adrenergic vasoconstriction in contracting forearm muscle of ageing men. J. Physiol. 567(Pt 1): 311-321. doi:10.1113/jphysiol. 2005.087668. PMID:15946964.

Donato, A.J., Lesniewski, L.A., and Delp, M.D. 2007. Ageing and exercise training alter adrenergic vasomotor responses of rat skeletal muscle arterioles. J. Physiol. 579(Pt 1): 115-125. doi:10.1113/jphysiol.2006.120055. PMID:17082231.

Ehlers, T.S., Sverrisdottir, Y., Bangsbo, J., and Gunnarsson, T.P. 2020. HighIntensity Interval Training Decreases Muscle Sympathetic Nerve Activity in Men with Essential Hypertension and in Normotensive Controls. Front. Neurosci. 14: 841. doi:10.3389/fnins.2020.00841. PMID:33013285.

Ettinger, S.M., Silber, D.H., Collins, B.G., Gray, K.S., Sutliff, G., Whisler, S.K., et al. 1996. Influences of gender on sympathetic nerve responses to static exercise. J. Appl. Physiol. (1985), 80(1): 245-251. doi:10.1152/jappl.1996.80.1.245. PMID:8847310.

Ettinger, S.M., Silber, D.H., Gray, K.S., Smith, M.B., Yang, Q.X., Kunselman, A.R., and Sinoway, L.I. 1998. Effects of the ovarian cycle on sympathetic neural outflow during static exercise. J. Appl. Physiol (1985). 85(6): 2075-2081. doi:10.1152/ jappl.1998.85.6.2075. PMID:9843528.

Fadel, P.J., Zhao, W., and Thomas, G.D. 2003. Impaired vasomodulation is associated with reduced neuronal nitric oxide synthase in skeletal muscle of ovariectomized rats. J. Physiol. 549(Pt 1): 243-253. doi:10.1113/jphysiol. 2003.038828. PMID:12665606.

Fadel, P.J., Wang, Z., Watanabe, H., Arbique, D., Vongpatanasin, W., and Thomas, G.D. 2004. Augmented sympathetic vasoconstriction in exercising forearms of postmenopausal women is reversed by oestrogen therapy. J. Physiol. 561(Pt 3): 893-901. doi:10.1113/jphysiol.2004.073619. PMID:9843528.

Gao, L., Wang, W., Liu, D., and Zucker, I.H. 2007. Exercise training normalizes sympathetic outflow by central antioxidant mechanisms in rabbits with pacing-induced chronic heart failure. Circulation, 115(24): 30953102. doi:10.1161/CIRCULATIONAHA.106.677989. PMID:17548725.

Grassi, G., Seravalle, G., Calhoun, D.A., and Mancia, G. 1994. Physical training and baroreceptor control of sympathetic nerve activity in humans. Hypertension, 23(3): 294-301. doi:10.1161/01.HYP.23.3.294. PMID:8125553.

Grassi, G., Biffi, A., Seravalle, G., Trevano, F.Q., Dell'Oro, R., Corrao, G., and Mancia, G. 2019. Sympathetic Neural Overdrive in the Obese and Overweight State. Hypertension, 74(2): 349-358. doi:10.1161/HYPERTENSIONAHA. 119.12885. PMID:31203727.

Hagbarth, K.E., and Vallbo, A.B. 1968. Pulse and respiratory grouping of sympathetic impulses in human muscle-nerves. Acta Physiol. Scand. 74(1): 96-108. doi:10.1111/j.1748-1716.1968.tb04218.x. PMID:4235387.

Hammer, L.W., and Boegehold, M.A. 2005. Functional hyperemia is reduced in skeletal muscle of aged rats. Microcirculation, 12(6): 517-526. doi:10.1080/ 10739680591003396. PMID:16147468.

Hansen, J., Sander, M., and Thomas, G.D. 2000. Metabolic modulation of sympathetic vasoconstriction in exercising skeletal muscle. Acta Physiol. Scand. 168(4): 489-503. doi:10.1046/j.1365-201x.2000.00701.x. PMID:10759586.

Hart, E.C., and Charkoudian, N. 2014. Sympathetic neural regulation of blood pressure: influences of sex and aging. Physiology (Bethesda), 29(1): 8-15. doi:10.1152/physiol.00031.2013. PMID:24382867.

Hart, E.C., Charkoudian, N., Wallin, B.G., Curry, T.B., Eisenach, J.H., and Joyner, M.J. 2009. Sex differences in sympathetic neural-hemodynamic 
balance: implications for human blood pressure regulation. Hypertension, 53 (3): 571-576. doi:10.1161/HYPERTENSIONAHA.108.126391. PMID:19171792.

Hart, E.C., Charkoudian, N., Wallin, B.G., Curry, T.B., Eisenach, J., and Joyner, M.J. 2011. Sex and ageing differences in resting arterial pressure regulation: the role of the beta-adrenergic receptors. J. Physiol. 589(Pt 21): 5285-5297. doi:10.1113/jphysiol.2011.212753.

Hearon, C.M., Jr., Richards, J.C., Racine, M.L., Luckasen, G.J., Larson, D.G., Joyner, M.J., and Dinenno, F.A. 2017. Sympatholytic effect of intravascular ATP is independent of nitric oxide, prostaglandins, $\mathrm{Na}(+) / \mathrm{K}(+)$-ATPase and KIR channels in humans. J. Physiol. 595(15): 5175-5190. doi:10.1113/ JP274532. PMID:28590059.

Hogarth, A.J., Mackintosh, A.F., and Mary, D.A. 2007. Gender-related differences in the sympathetic vasoconstrictor drive of normal subjects. Clin. Sci. (Lond.), 112(6): 353-361. doi:10.1042/CS20060288. PMID:17129210.

Jackson, D.N., Milne, K.J., Noble, E.G., and Shoemaker, J.K. 2005. Gendermodulated endogenous baseline neuropeptide Y Y1-receptor activation in the hindlimb of Sprague-Dawley rats. J. Physiol. 562(Pt 1): 285-294. doi:10.1113/jphysiol.2004.076141. PMID:15513938.

Jarvis, S.S., VanGundy, T.B., Galbreath, M.M., Shibata, S., Okazaki, K., Reelick, M.F., et al. 2011. Sex differences in the modulation of vasomotor sympathetic outflow during static handgrip exercise in healthy young humans. Am. J. Physiol. Regul. Integr. Comp. Physiol. 301(1): R193-200. doi:10.1152/ajpregu.00562.2010. PMID:21508291.

Jasperse, J.L., and Laughlin, M.H. 1999. Vasomotor responses of soleus feed arteries from sedentary and exercise-trained rats. J. Appl. Physiol. (1985), 86(2): 441-449. doi:10.1152/jappl.1999.86.2.441. PMID:9931174.

Jendzjowsky, N.G., and DeLorey, D.S. 2012. Short-term exercise training augments sympathetic vasoconstrictor responsiveness and endotheliumdependent vasodilation in resting skeletal muscle. Am. J. Physiol. Regul. Integr. Comp. Physiol. 303(3): R332-9. doi:10.1152/ajpregu.00053.2012. PMID:22696575.

Jendzjowsky, N.G., and DeLorey, D.S. 2013a. Acute superoxide scavenging reduces sympathetic vasoconstrictor responsiveness in short-term exercisetrained rats. J. Appl. Physiol. 114(11): 1511-1518. doi:10.1152/japplphysiol.00131. 2013. PMID:23558386.

Jendzjowsky, N.G., and DeLorey, D.S. 2013b. Role of neuronal nitric oxide in the inhibition of sympathetic vasoconstriction in resting and contracting skeletal muscle of healthy rats. J. Appl. Physiol. 115(1): 97-106. doi:10.1152/ japplphysiol.00250.2013. PMID:23640592.

Jendzjowsky, N.G., and DeLorey, D.S. 2013c. Short-term exercise training augments 2-adrenoreceptor-mediated sympathetic vasoconstriction in resting and contracting skeletal muscle. J. Physiol. 591(Pt 20): 5221-5233. doi:10.1113/jphysiol.2013.257626. PMID:23940382.

Jendzjowsky, N.G., and DeLorey, D.S. 2013d. Short-term exercise training enhances functional sympatholysis through a nitric oxide-dependent mechanism. J. Physiol. 591(Pt 6): 1535-1549. doi:10.1113/jphysiol.2012.238998. PMID:23297301.

Jendzjowsky, N.G., Just, T.P., and DeLorey, D.S. 2014a. Exercise training augments neuronal nitric oxide synthase-mediated inhibition of sympathetic vasoconstriction in contracting skeletal muscle of rats. J. Physiol. 592(21): 4789-4802. doi:10.1113/jphysiol.2014.278846. PMID:25194041.

Jendzjowsky, N.G., Just, T.P., Jones, K.E., and DeLorey, D.S. 2014b. Acute tetrahydrobiopterin supplementation attenuates sympathetic vasoconstrictor responsiveness in resting and contracting skeletal muscle of healthy rats. Physiol. Rep. 2(10): e12164. doi:10.14814/phy2.12164. PMID:25318748.

Johnson, C.D., and Gilbey, M.P. 1996. On the dominant rhythm in the discharges of single postganglionic sympathetic neurones innervating the rat tail artery. J. Physiol. 497 (Pt 1): 241-259. doi:10.1113/jphysiol.1996. sp021764. PMID:8951726.

Johnson, C.D., Coney, A.M., and Marshall, J.M. 2001. Roles of norepinephrine and ATP in sympathetically evoked vasoconstriction in rat tail and hindlimb in vivo. Am. J. Physiol. Heart Circ. Physiol. 281(6): H2432-40. doi:10.1152/ajpheart.2001.281.6.H2432. PMID:11709409.

Jones, P.P., Davy, K.P., Alexander, S., and Seals, D.R. 1997a. Age-related increase in muscle sympathetic nerve activity is associated with abdominal adiposity. Am. J. Physiol. 272(6 Pt 1): E976-80. doi:10.1152/ajpendo.1997.272.6.E976. PMID:9227440.

Jones, P.P., Davy, K.P., and Seals, D.R. 1997b. Relations of total and abdominal adiposity to muscle sympathetic nerve activity in healthy older males. Int. J. Obes. 21(11): 1053-1057. doi:10.1038/sj.ijo.0800515. PMID:9368830.

Joyner, M.J., and Green, D.J. 2009. Exercise protects the cardiovascular system: effects beyond traditional risk factors. J. Physiol. 587(Pt 23): 55515558. doi:10.1113/jphysiol.2009.179432. PMID:19736305.

Just, T.P., and DeLorey, D.S. 2016. Exercise training and alpha1-adrenoreceptormediated sympathetic vasoconstriction in resting and contracting skeletal muscle. Physiol. Rep. 4(3): e12707. doi:10.14814/phy2.12707. PMID:26869686.

Just, T.P., and DeLorey, D.S. 2017. Sex differences in sympathetic vasoconstrictor responsiveness and sympatholysis. J. Appl. Physiol. (1985), 123(1): 128-135. doi:10.1152/japplphysiol.00139.2017. PMID:28473610.

Just, T.P., Cooper, I.R., and DeLorey, D.S. 2016. Sympathetic vasoconstriction in skeletal muscle: adaptations to exercise training. Exerc. Sport Sci. Rev. 44(4): 137-143. doi:10.1249/JES.0000000000000085. PMID:27433976.

Keir, D.A., Badrov, M.B., Tomlinson, G., Notarius, C.F., Kimmerly, D.S., Millar, P.J., et al. 2020. Influence of sex and age on muscle sympathetic nerve activity of healthy normotensive adults. Hypertension, 76(3): 997-1005. doi:10.1161/HYPER TENSIONAHA.120.15208. PMID:32783757.
Kirby, B.S., Voyles, W.F., Carlson, R.E., and Dinenno, F.A. 2008. Graded sympatholytic effect of exogenous ATP on postjunctional alpha-adrenergic vasoconstriction in the human forearm: implications for vascular control in contracting muscle. J. Physiol. 586(17): 4305-4316. doi:10.1113/jphysiol. 2008.154252. PMID:18617568.

Kirby, B.S., Crecelius, A.R., Voyles, W.F., and Dinenno, F.A. 2011. Modulation of postjunctional alpha-adrenergic vasoconstriction during exercise and exogenous ATP infusions in ageing humans. J. Physiol. 589(Pt 10): 26412653. doi:10.1113/jphysiol.2010.204081. PMID:21486772.

Kirby, B.S., Crecelius, A.R., Voyles, W.F., and Dinenno, F.A. 2012. Impaired skeletal muscle blood flow control with advancing age in humans: attenuated ATP release and local vasodilation during erythrocyte deoxygenation. Circ. Res. 111(2): 220-230. doi:10.1161/CIRCRESAHA.112.269571. PMID:22647875.

Kneale, B.J., Chowienczyk, P.J., Brett, S.E., Coltart, D.J., and Ritter, J.M. 2000. Gender differences in sensitivity to adrenergic agonists of forearm resistance vasculature. J. Am. Coll. Cardiol. 36(4): 1233-1238. doi:10.1016/S07351097(00)00849-4. PMID:11028476.

Koch, D.W., Leuenberger, U.A., and Proctor, D.N. 2003. Augmented leg vasoconstriction in dynamically exercising older men during acute sympathetic stimulation. J. Physiol. 551(Pt 1): 337-344. doi:10.1113/jphysiol.2003.042747. PMID:12824451.

Lash, J.M. 1998. Exercise training enhances adrenergic constriction and dilation in the rat spinotrapezius muscle. J. Appl. Physiol. (1985), 85(1): 168174. doi:10.1152/jappl.1998.85.1.168. PMID:9655771.

Lash, J.M., and Bohlen, H.G. 1992. Functional adaptations of rat skeletal muscle arterioles to aerobic exercise training. J. Appl. Physiol. (1985), 72(6): 2052-2062. doi:10.1152/jappl.1992.72.6.2052. PMID:1629056.

Lawrenson, L., Poole, J.G., Kim, J., Brown, C., Patel, P., and Richardson, R.S. 2003. Vascular and metabolic response to isolated small muscle mass exercise: effect of age. Am. J. Physiol. Heart Circ. Physiol. 285(3): H1023H1031. doi:10.1152/ajpheart.00135.2003. PMID:12738622.

Limberg, J.K., Eldridge, M.W., Proctor, L.T., Sebranek, J.J., and Schrage, W.G. 2010. Alpha-adrenergic control of blood flow during exercise: effect of sex and menstrual phase. J. Appl. Physiol. (1985), 109(5): 1360-1368. doi:10.1152/japplphysiol.00518.2010. PMID:20724565.

Limberg, J.K., Johansson, R.E., Peltonen, G.L., Harrell, J.W., Kellawan, J.M., Eldridge, M.W., et al. 2016. $\beta$-Adrenergic-mediated vasodilation in young men and women: cyclooxygenase restrains nitric oxide synthase. Am. J. Physiol. Heart Circ. Physiol. 310(6): H756-64. doi:10.1152/ajpheart.00886.2015. PMID:26747505.

Lind, L., and Lithell, H. 1993. Decreased peripheral blood flow in the pathogenesis of the metabolic syndrome comprising hypertension, hyperlipidemia, and hyperinsulinemia. Am. Heart J. 125(5 Pt 2): 1494-1497. doi:10.1016/ 0002-8703(93)90446-G. PMID:8480620.

Liu, J.L., Irvine, S., Reid, I.A., Patel, K.P., and Zucker, I.H. 2000. Chronic exercise reduces sympathetic nerve activity in rabbits with pacing-induced heart failure: A role for angiotensin II. Circulation, 102(15): 1854-1862. doi:10.1161/01.CIR.102.15.1854. PMID:11023943.

Maranon, R., and Reckelhoff, J.F. 2013. Sex and gender differences in control of blood pressure. Clin. Sci. (Lond.), 125(7): 311-318. doi:10.1042/CS20 130140. PMID:23746374.

Martin, W.H., Ogawa, T., Kohrt, W.M., Malley, M.T., Korte, E., Kieffer, P.S., and Schechtman, K.B. 1991. Effects of aging, gender, and physical training on peripheral vascular function. Circulation, 84(2): 654-664. doi:10.1161/ 01.CIR.84.2.654. PMID:1860209.

Matsukawa, T., Sugiyama, Y., Watanabe, T., Kobayashi, F., and Mano, T. 1998. Gender difference in age-related changes in muscle sympathetic nerve activity in healthy subjects. Am. J. Physiol. 275(5 Pt 2): R1600R1604. doi:10.1152/ajpregu.1998.275.5.R1600. PMID:9791079.

Mazzeo, R.S., Rajkumar, C., Jennings, G., and Esler, M. 1997. Norepinephrine spillover at rest and during submaximal exercise in young and old subjects. J. Appl. Physiol. 82(6): 1869-1874. doi:10.1152/jappl.1997.82.6.1869. PMID:9173952

McAllister, R.M., and Laughlin, M.H. 1997. Short-term exercise training alters responses of porcine femoral and brachial arteries. J. Appl. Physiol. 82(5): 1438-1444. doi:10.1152/jappl.1997.82.5.1438. PMID:9134890.

Minson, C.T., Halliwill, J.R., Young, T.M., and Joyner, M.J. 2000. Influence of the menstrual cycle on sympathetic activity, baroreflex sensitivity, and vascular transduction in young women. Circulation, 101(8): 862-868. doi:10.1161/01.CIR.101.8.862. PMID:10694525.

Mizuno, M., Iwamoto, G.A., Vongpatanasin, W., Mitchell, J.H., and Smith, S.A. 2014. Exercise training improves functional sympatholysis in spontaneously hypertensive rats through a nitric oxide-dependent mechanism. Am. J. Physiol. Heart Circ. Physiol. 307(2): H242-H251. doi:10.1152/ajpheart.00103. 2014. PMID:24816260.

Moreau, K.L., Donato, A.J., Tanaka, H., Jones, P.P., Gates, P.E., and Seals, D.R. 2003. Basal leg blood flow in healthy women is related to age and hormone replacement therapy status. J. Physiol. 547(Pt 1): 309-316. doi:10.1113/jphysiol. 2002.032524. PMID:12562958.

Moreau, K.L., DePaulis, A.R., Gavin, K.M., and Seals, D.R. 2007. Oxidative stress contributes to chronic leg vasoconstriction in estrogen-deficient postmenopausal women. J. Appl. Physiol. 102(3): 890-895. doi:10.1152/japplphysiol.008 77.2006. PMID:17110511.

Mortensen, S.P., Nyberg, M., Winding, K., and Saltin, B. 2012. Lifelong physical activity preserves functional sympatholysis and purinergic signalling in the ageing human leg. J. Physiol. 590(23): 6227-6236. doi:10.1113/jphysiol. 2012.240093. PMID:22966164. 
Mortensen, S.P., McAllister, R.M., Yang, H.T., Hellsten, Y., and Laughlin, M.H. 2014a. The effect of purinergic P2 receptor blockade on skeletal muscle exercise hyperemia in miniature swine. Eur. J. Appl. Physiol. 114(10): 2147-2155. doi:10.1007/s00421-014-2932-8. PMID:24962002.

Mortensen, S.P., Nyberg, M., Gliemann, L., Thaning, P., Saltin, B., and Hellsten, Y. 2014b. Exercise training modulates functional sympatholysis and $\alpha$-adrenergic vasoconstrictor responsiveness in hypertensive and normotensive individuals. J. Physiol. 592(14): 3063-3073. doi:10.1113/jphysiol. 2014.273722. PMID:24860173.

Mueller, P.J. 2007. Exercise training attenuates increases in lumbar sympathetic nerve activity produced by stimulation of the rostral ventrolateral medulla. J. Appl. Physiol. 102(2): 803-813. doi:10.1152/japplphysiol.00498.2006. PMID:17053106.

Mueller, P.J. 2010. Physical (in)activity-dependent alterations at the rostral ventrolateral medulla: influence on sympathetic nervous system regulation. Am. J. Physiol. Regul. Integr. Comp. Physiol. 298(6): R1468-R1474. doi:10.1152/ajpregu.00101.2010. PMID:20357021.

Muller-Delp, J., Spier, S.A., Ramsey, M.W., Lesniewski, L.A., Papadopoulos, A. Humphrey, J.D., and Delp, M.D. 2002. Effects of aging on vasoconstrictor and mechanical properties of rat skeletal muscle arterioles. Am. J. Physiol. Heart Circ. Physiol. 282(5): H1843-H1854. doi:10.1152/ajpheart.00666.2001. PMID:11959651.

Narkiewicz, K., Phillips, B.G., Kato, M., Hering, D., Bieniaszewski, L., and Somers, V.K. 2005. Gender-selective interaction between aging, blood pressure, and sympathetic nerve activity. Hypertension, 45(4): 522-525. doi:10.1161/01.HYP.0000160318.46725.46. PMID:15767469.

Ng, A.V., Callister, R., Johnson, D.G., and Seals, D.R. 1993. Age and gender influence muscle sympathetic nerve activity at rest in healthy humans. Hypertension, 21(4): 498-503. doi:10.1161/01.HYP.21.4.498. PMID:8458648.

Ng, A.V., Callister, R., Johnson, D.G., and Seals, D.R. 1994. Endurance exercise training is associated with elevated basal sympathetic nerve activity in healthy older humans. J. Appl. Physiol. 77(3): 1366-1374. doi:10.1152/ jappl.1994.77.3.1366. PMID:7836141.

Notarius, C.F., Murai, H., Morris, B.L., and Floras, J.S. 2012. Effect of fitness on reflex sympathetic neurovascular transduction in middle-age men. Med. Sci. Sports Exerc. 44(2): 232-237. doi:10.1249/MSS.0b013e31822a68a5. PMID:21701410.

Nyberg, M., Blackwell, J.R., Damsgaard, R., Jones, A.M., Hellsten, Y., and Mortensen, S.P. 2012. Lifelong physical activity prevents an age-related reduction in arterial and skeletal muscle nitric oxide bioavailability in humans. J. Physiol. 590(21): 5361-5370. doi:10.1113/jphysiol.2012.239053. PMID:22890714.

O'Hagan, K.P., Bell, L.B., Mittelstadt, S.W., and Clifford, P.S. 1993. Effect of dynamic exercise on renal sympathetic nerve activity in conscious rabbits. J. Appl. Physiol. 74(5): 2099-2104. doi:10.1152/jappl.1993.74.5.2099. PMID:8335535.

Ohyanagi, M., Nishigaki, K., and Faber, J.E. 1992. Interaction between microvascular alpha 1- and alpha 2-adrenoceptors and endothelium-derived relaxing factor. Circ. Res. 71(1): 188-200. doi:10.1161/01.res.71.1.188. PMID:1318795.

O'Leary, D.S., Robinson, E.D., and Butler, J.L. 1997. Is active skeletal muscle functionally vasoconstricted during dynamic exercise in conscious dogs? Am. J. Physiol. Regul. Integr. Comp. Physiol. 272(1): R386-R391. doi:10.1152/ ajpregu.1997.272.1.R386. PMID:9039033.

Owlya, R., Vollenweider, L., Trueb, L., Sartori, C., Lepori, M., Nicod, P., and Scherrer, U. 1997. Cardiovascular and sympathetic effects of nitric oxide inhibition at rest and during static exercise in humans. Circulation, 96(11): 3897-3903. doi:10.1161/01.CIR.96.11.3897. PMID:9403613.

Parker, B.A., Smithmyer, S.L., Jarvis, S.S., Ridout, S.J., Pawelczyk, J.A., and Proctor, D.N. 2007. Evidence for reduced sympatholysis in leg resistance vasculature of healthy older women. Am. J. Physiol. Heart Circ. Physiol. 292(2): H1148-H1156. doi:10.1152/ajpheart.00729.2006. PMID:17071730.

Paterson, D.H., Govindasamy, D., Vidmar, M., Cunningham, D.A., and Koval, J.J. 2004. Longitudinal study of determinants of dependence in an elderly population. J. Am. Geriatr. Soc. 52(10): 1632-1638. doi:10.1111/ j.1532-5415.2004.52454.x. PMID:15450038.

Paterson, D.H., Jones, G.R., and Rice, C.L. 2007. Ageing and physical activity: evidence to develop exercise recommendations for older adults. Appl. Physiol. Nutr. Metab. 32(Suppl 2): S69-108. doi:10.1139/H07-111. PMID:18213941.

Pellinger, T.K., and Halliwill, J.R. 2007. Effect of propranolol on sympathetically mediated leg vasoconstriction in humans. J. Physiol. 583(Pt 2): 797809. doi:10.1113/jphysiol.2007.137422. PMID:17627989.

Pernow, J., Schwieler, J., Kahan, T., Hjemdahl, P., Oberle, J., Wallin, B.G., and Lundberg, J.M. 1989. Influence of sympathetic discharge pattern on norepinephrine and neuropeptide Y release. Am. J. Physiol. 257(3 Pt 2): H866-H872. doi:10.1152/ajpheart.1989.257.3.H866. PMID:2782443.

Peronn, F., Cleroux, J., Perrault, H., Cousineau, D., de Champlain, J., and Nadeau, R. 1981. Plasma norepinephrine response to exercise before and after training in humans. J. Appl. Physiol. Respir. Environ. Exerc. Physiol. 51(4): 812-815. doi:10.1152/jappl.1981.51.4.812. PMID:7298422.

Poole, J.G., Lawrenson, L., Kim, J., Brown, C., and Richardson, R.S. 2003. Vascular and metabolic response to cycle exercise in sedentary humans: effect of age. Am. J. Physiol. Heart Circ. Physiol. 284(4): H1251-H1259. doi:10.1152/ajpheart.00790.2002. PMID:12595287.

Proctor, D.N., Shen, P.H., Dietz, N.M., Eickhoff, T.J., Lawler, L.A., Ebersold, E.J., et al. 1998. Reduced leg blood flow during dynamic exercise in older endurance- trained men. J. Appl. Physiol. 85(1): 68-75. doi:10.1152/ jappl.1998.85.1.68. PMID:9655757.
Proctor, D.N., Koch, D.W., Newcomer, S.C., Le, K.U., and Leuenberger, U.A. 2003a. Impaired leg vasodilation during dynamic exercise in healthy older women. J. Appl. Physiol. 95(5): 1963-1970. doi:10.1152/japplphysiol. 00472.2003. PMID:12882993.

Proctor, D.N., Newcomer, S.C., Koch, D.W., Le, K.U., MacLean, D.A., and Leuenberger, U.A. 2003b. Leg blood flow during submaximal cycle ergometry is not reduced in healthy older normally active men. J. Appl. Physiol. 94(5): 1859-1869. doi:10.1152/japplphysiol.00898.2002. PMID:12547841.

Ray, C.A. 1999. Sympathetic adaptations to one-legged training. J. Appl. Physiol. 86(5): 1583-1587. doi:10.1152/jappl.1999.86.5.1583. PMID:10233121.

Remensnyder, J.P., Mitchell, J.H., and Sarnoff, S.J. 1962. Functional sympatholysis during muscular activity. Observations on influence of carotid sinus on oxygen uptake. Circ. Res. 11: 370-380. doi:10.1161/01.RES.11.3.370. PMID:13981593.

Revington, M., and McCloskey, D.I. 1988. Neuropeptide Y and control of vascular resistance in skeletal muscle. Regul. Pept. 23(3): 331-342. doi:10.1016/01670115(88)90234-0. PMID:3238054.

Rosenmeier, J.B., Hansen, J., and Gonzalez-Alonso, J. 2004. Circulating ATPinduced vasodilatation overrides sympathetic vasoconstrictor activity in human skeletal muscle. J. Physiol. 558(Pt 1): 351-365. doi:10.1113/jphysiol. 2004.063107. PMID:15155791.

Rowell, L.B. 1993. Human cardiovascular control. Oxford University Press, New York, N.Y., USA.

Saleh, M.C., Connell, B.J., and Saleh, T.M. 2000. Autonomic and cardiovascular reflex responses to central estrogen injection in ovariectomized female rats. Brain Res. 879(1-2): 105-114. doi:10.1016/S0006-8993(00)02757-8. PMID:11011011.

Saleh, T.M., and Connell, B.J. 2007. Role of oestrogen in the central regulation of autonomic function. Clin. Exp. Pharmacol. Physiol. 34(9): 827832. doi:10.1111/j.1440-1681.2007.04663.x. PMID:17645624.

Sander, M., Chavoshan, B., Harris, S.A., Iannaccone, S.T., Stull, J.T., Thomas, G.D., and Victor, R.G. 2000. Functional muscle ischemia in neuronal nitric oxide synthase-deficient skeletal muscle of children with Duchenne muscular dystrophy. Proc. Natl. Acad. Sci. U.S.A. 97(25): 1381813823. doi:10.1073/pnas.250379497. PMID:11087833.

Savard, G., Strange, S., Kiens, B., Richter, E.A., Christensen, N.J., and Saltin, B. 1987. Noradrenaline spillover during exercise in active versus resting skeletal muscle in man. Acta Physiol. Scand. 131(4): 507-515. doi:10.1111/j.1748-1716.1987.tb08270.x. PMID:3442240.

Seals, D.R. 1991. Sympathetic neural adjustments to stress in physically trained and untrained humans. Hypertension, 17(1): 36-43. doi:10.1161/01. HYP.17.1.36. PMID:1986981.

Sheldahl, L.M., Ebert, T.J., Cox, B., and Tristani, F.E. 1994. Effect of aerobic training on baroreflex regulation of cardiac and sympathetic function. J. Appl. Physiol. 76(1): 158-165. doi:10.1152/jappl.1994.76.1.158. PMID:8175501.

Sinoway, L., Shenberger, J., Leaman, G., Zelis, R., Gray, K., Baily, R., and Leuenberger, U. 1996. Forearm training attenuates sympathetic responses to prolonged rhythmic forearm exercise. J. Appl. Physiol. 81(4): 17781784. doi:10.1152/jappl.1996.81.4.1778. PMID:8904599.

Smith, E.G., Voyles, W.F., Kirby, B.S., Markwald, R.R., and Dinenno, F.A. 2007. Ageing and leg postjunctional alpha-adrenergic vasoconstrictor responsiveness in healthy men. J. Physiol. 582(Pt 1): 63-71. doi:10.1113/ jphysiol.2007.130591. PMID:17463044.

Somers, V.K., Leo, K.C., Shields, R., Clary, M., and Mark, A.L. 1992. Forearm endurance training attenuates sympathetic nerve response to isometric handgrip in normal humans. J. Appl. Physiol (1985). 72(3): 1039-1043. doi:10.1152/jappl.1992.72.3.1039. PMID:1568957.

Spier, S.A., Delp, M.D., Stallone, J.N., Dominguez, J.M., and Muller-Delp, J.M. 2007. Exercise training enhances flow-induced vasodilation in skeletal muscle resistance arteries of aged rats: role of PGI2 and nitric oxide. Am. J. Physiol. Heart Circ. Physiol. 292(6): H3119-H3127. doi:10.1152/ajpheart.00588.2006. PMID:17337602.

Sugawara, J., Komine, H., Hayashi, K., Yoshizawa, M., Otsuki, T., Shimojo, N., et al. 2007. Systemic alpha-adrenergic and nitric oxide inhibition on basal limb blood flow: effects of endurance training in middle-aged and older adults. Am. J. Physiol. Heart Circ. Physiol. 293(3): H1466-72. doi:10.1152/ ajpheart.00273.2007. PMID:17496216.

Sullivan, J.C., and Davison, C.A. 2001. Gender differences in the effect of age on electrical field stimulation (EFS)-induced adrenergic vasoconstriction in rat mesenteric resistance arteries. J. Pharmacol. Exp. Ther. 296(3): 782788. PMID:11181907.

Sun, D., Huang, A., Koller, A., and Kaley, G. 1994. Short-term daily exercise activity enhances endothelial NO synthesis in skeletal muscle arterioles of rats. J. Appl. Physiol. (1985), 76(5): 2241-2247. doi:10.1152/jappl.1994.76.5.2241. PMID:7520432.

Sundlof, G., and Wallin, B.G. 1977. The variability of muscle nerve sympathetic activity in resting recumbent man. J. Physiol. 272(2): 383-397. doi:10.1113/jphysiol.1977.sp012050. PMID:592196.

Svedenhag, J., Wallin, B.G., Sundlof, G., and Henriksson, J. 1984. Skeletal muscle sympathetic activity at rest in trained and untrained subjects. Acta Physiol. Scand. 120(4): 499-504. doi:10.1111/j.1748-1716.1984.tb07413.x. PMID:6485828.

Taddei, S., Virdis, A., Ghiadoni, L., Salvetti, G., Bernini, G., Magagna, A., and Salvetti, A. 2001. Age-related reduction of NO availability and oxidative stress in humans. Hypertension, 38(2): 274-279. doi:10.1161/01.HYP.38.2.274. PMID:11509489. 
Tanabe, T., Maeda, S., Miyauchi, T., Iemitsu, M., Takanashi, M., IrukayamaTomobe, Y., et al. 2003. Exercise training improves ageing-induced decrease in eNOS expression of the aorta. Acta Physiol. Scand. 178(1): 310. doi:10.1046/j.1365-201X.2003.01100.x. PMID:12713509.

Tank, J. 2005. Does aging cause women to be more sympathetic than men? Hypertension, 45(4): 489-490. doi:10.1161/01.HYP.0000160319.33841.ff. PMID:15767468.

Thijssen, D.H.J., Maiorana, A.J., O’Driscoll, G., Cable, N.T., Hopman, M.T.E., and Green, D.J. 2010. Impact of inactivity and exercise on the vasculature in humans. Eur. J. Appl. Physiol. 108(5): 845-875. doi:10.1007/s00421-0091260-x. PMID:19943061.

Thomas, G.D., and Segal, S.S. 2004. Neural control of muscle blood flow during exercise. J. Appl. Physiol. (1985), 97(2): 731-738. doi:10.1152/japplphysiol.00076. 2004. PMID:15247201.

Thomas, G.D., and Victor, R.G. 1998. Nitric oxide mediates contractioninduced attenuation of sympathetic vasoconstriction in rat skeletal muscle. J. Physiol (Lond). 506(3): 817-826. doi:10.1111/j.1469-7793.1998.817bv.x. PMID:9503340.

Vongpatanasin, W., Tuncel, M., Mansour, Y., Arbique, D., and Victor, R.G. 2001. Transdermal estrogen replacement therapy decreases sympathetic activity in postmenopausal women. Circulation, 103(24): 2903-2908. doi:10.1161/01.cir.103.24.2903. PMID:11413078.

Wiegman, D.L., Harris, P.D., Joshua, I.G., and Miller, F.N. 1981. Decreased vascular sensitivity to norepinephrine following exercise training. J. Appl. Physiol. Respir. Environ. Exerc. Physiol. 51(2): 282-287. doi:10.1152/ jappl.1981.51.2.282. PMID:7263435.

Winder, W.W., Hagberg, J.M., Hickson, R.C., Ehsani, A.A., and McLane, J.A. 1978. Time course of sympathoadrenal adaptation to endurance exercise training in man. J. Appl. Physiol. Respir. Environ. Exerc. Physiol. 45(3): 370-374. doi:10.1152/jappl.1978.45.3.370. PMID:701121.

Winder, W.W., Hickson, R.C., Hagberg, J.M., Ehsani, A.A., and McLane, J.A. 1979. Training-induced changes in hormonal and metabolic responses to submaximal exercise. J. Appl. Physiol. Respir. Environ. Exerc. Physiol. 46(4): 766-771. doi:10.1152/jappl.1979.46.4.766. PMID:457555.

Wray, D.W., Nishiyama, S.K., and Richardson, R.S. 2009. Role of \{alpha\}1-adrenergic vasoconstriction in the regulation of skeletal muscle blood flow with advancing age. Am. J. Physiol. Heart Circ. Physiol. 296(2): H497H504. doi:10.1152/ajpheart.01016.2008. PMID:19060122. 